\title{
PENERAPAN DIVERSI SEBAGAI IMPLEMENTASI PEMENUHAN HAK ASASI ANAK YANG BERKONFLIK DENGAN HUKUM
}

\author{
${ }^{1}$ Luh Sri Widi Artini, ${ }^{2}$ Putu Bagus Sabda Pramesti \\ Politeknik IImu Pemasyarakatan \\ luhwidi51@gmail.com, sabdabagus@gmail.com
}

Cinere-Depok, 16512, Indonesia

\begin{abstract}
A child who commits a legal offence is a special concern from the state. Diversi is the application of versioning is an effort from the government to protect the child from negative stigmatization and based on the best needs and interests for children, by seeking a version through the approach of Restorative justice. This research aims to determine how the implementation is versioned as a child's human rights implementation and what constraints are faced by related parties in the running of versioning. This research uses a qualitative method of research approach with a literature study technique that is further analyzed qualitatively. Children are trusting and give that must be guarded because the child is the hope of the state as a nation's successor so that children should be protected. The results of this study show that versioning is one of the government's efforts to protect the child's rights from adverse influences and the stigmatization of the community and is done for the best interest of the child. Obstacles faced in the form of lack of the presence and the existence of a sectoral ego between the law enforcement officers so that the version has not run optimally and the need to socialize about the law of the Child criminal system Community.
\end{abstract}

Keywords: Child's human right; Diversi, Restorative Justice

\begin{abstract}
Abstrak
Anak adalah anugerah dan amanah yang harus dijaga karena anak adalah harapan Negara sebagai penerus bangsa sehingga anak harus dilindungi. Anak yang melakukan pelanggaran hukum menjadi perhatian khusus dari Negara. Penerapan diversi merupakan upaya dari pemerintah untuk melindungi anak dari stigmatisasi negative dan berdasarkan pada kebutuhan dan kepentingan terbaik bagi anak, dengan mengupayakan diversi melalui pendekatan restoratife justice. Penelitian ini bertujuan untuk mengetahui bagaimana penerapan diversi sebagai implementasi hak asasi manusia anak dan apa kendala yang dihadapi oleh pihak terkait dalam menjalankan diversi. Penelitian ini menggunakan metode pendekatan penelitian kualitatif dengan teknik studi kepustakaan yang selanjutnya dianalisis secara kualitatif. Hasil dari penelitian ini menunjukan bahwa diversi adalah salah satu upaya pemerintah Negara untuk melindungi hak asasi anak dari adanya pengaruh buruk dan stigmatisasi dari masyarakat dan dilakukan untuk kepentingan terbaik bagi anak. Kendala yang dihadapi berupa kurangnya pehamanan dan adanya ego sectoral antara aparat penegak hukum sehingga diversi belum berjalan secara maksimal dan perlunya sosialisasi mengenai Undang-Undang Sistem Perdailan Pidana Anak khususnya diversi kepada masyarakat.
\end{abstract}

Kata Kunci: Diversi; Hak Asasi Anak; Pemulihan Keadilan,

Open Access at: http://ojs.uho.ac.id/index.php/PUBLICUHO/index

Journal Publicuho is licensed under a Creative Commons Attribution 4.0 International License. 


\section{PENDAHULUAN}

Anugerah terindah yang dimiliki dalam berkelvarga adalah di karuniai seorang anak, sejak hidup anak sudah memiliki harkat dan martabat sebagai manusia seutuhnya dalam dirinya. Kehadiran eorang anak di tengah-tengah kelivarga merupakan hal terindah dan menghiasi hari-hari bagi kedua orang tuanya. Pendampingan dari kedua orang tua menentukan karakteristik anak kedepannya. Sebagai genersi muda penerus bangsa seorang anak diharapkan mampu mewujudkan cita-cita dan membangun bangsa menjadi lebi baik. Anak menurut UU No. 35 Tahun 2014 tentang Perubahan atas UU No. 23 Tahun 2002 Tentang Perlindungan Anak, merupakan seseorang yang belumberusia 18 (delapan belas) termasuk yang masih didalam kandungan.

Anak pada proses perkembangan dan pertumbuhannya dari janin didalam kandungan hingga dewasa akan terbentuk kepribadian / karakteristiknya yang dipengaruh oleh berbagai faktor internal dan eksternal, yang mana proses tersebut anak dapat melakukan tindakan yang bertentangan dengan hukum pidana atau perbuatan yang dipandang oleh masyarakat sebagai perbuatan yang tercela.(Krisna, 2018) Di era modern ini, masalah kriminalitas tidak dapat dihindari dan akan selalu berkembang. Masalah kriminalitas berkembang sejalan dengan kemajuan ilmu teknologi (IPTEK). Akibat dari kemajuan dan perkembangan tersebut bukan hanya orang dewasa tetapi juga berpengaruh terhadap tingkah laku anak-anak. Sorang anak jika kurang mendapatkan perhatian yang baik dari orang tua dan keluarganya cenderung melakukan pelanggaran norma, baik norma kesusilaan ataupun norma hukum yang dapat menimbulkan kerugian untuk dirinya sendiri, kelvarga dan masyarakat.

Tingginya tindak criminal yang disebabkan oleh anak-anak mengakibatkan bertambahnya anak-anak yang terlibat dalam konflik hukum. Pada usia perkembangan dan pertumbuhan anak, baik secara fisik maupun mental mereka memerlukan jaminan berupa perlindungan dan pembinaan. Di Indonesia, kasus hukum yang menimpa anak-anak semakin meningkat. Tidak hanya kasus-kasus hukum ringan tetapi juga sampai kasus yang dianggap sangat serius seperti pembunuhan, pelecehan seksual, pencurian, dan lain-lain. Anak dirasa belum mampu mempertanggungjawabkan atas apa yang telah diperbuatnya. Perilaku-prilaku menyimpang anak tersebut cenderung dpengaruh oleh lingkungan sosialnya baik itu disekolah atau dimasyarakat dan keluarganya.

Maka dari itu diperlukan upaya preventif melalui instrument hukum untuk meminimalisir penjatuhan pidana bagi anak untuk kepentingan terbaik bagi anak.

Anak Berkonflik dengan Hukum menurut UU No. 11 Tahun 2012 Tentang Sistem Peradilan Pidana Anak, Pasal 1 angka (3), Anak yang berkonflik dengan hukum adalah anak yang telah berumur 12 (dua belas) tahun, tetapi belum berumur 18 (delapan belas) tahun yang 
diduga melakukan tindak pidana. Ketika anak ada pada posisi berhadapan dengan hukum, ia memiliki hak yang istimewa yaitu dalam penanganan kasus hukum yang dijalaninya harus di berikan perlakuan yang berbeda dengan orang dewasa. Perlakuan istimewa bagi anak sebagaimana dicatat oleh Green Wood yang dituangkan dalam prinsip Juvenile Court di Amerika serikat, antara lain :

1. Menjunjung asas praduga tak bersalah (Presumption of innocenct). artinya, anak yang diduga melakukan pelanggaran hukum tidak boleh dicap sebagai pelaku kriminal melainkan sebagai perilaku delikuensi dan merupakan implementasi dari anak yang belum mampu bertanggung jawab atas perbuatannya.

2. Penempatan anak di dalam Lembaga bukan sebagai penghukuman melainkan untuk mendapatkan pembinaan dan resosialisasi sementara pada orang dewasa vonis. Artinya anak ditempatkan di lembaga bukan untuk diberikan efek jera sebagai konsekuensi dari apa yang telah dilakukan oleh anak tersebut, melainkan anak di dalam Lembaga di bina dan bimbing untuk sehingga anak menjadi pribadi yang lebih baik dan memiliki keterampilan yang bagus.

3. Dalam proses persidangan anak bersifat tertutup, artinya pada saat anak disidangkan dalam persidangan, yang mengetahui dan terlibat hanyalah pihak keluarga dan pihak pihak lain yang memang sudah diatur dalam Undang-Undang. Pihak-pihak lain tersebut adalah kepolisian, jaksa, pembimbing kemasyarakatan, pekerja social, dan pengacara.

4. Pada saat anak dalam masa peradilan, anak wajib mendapat social report dari seorang pekerja social yang dihadirkan. Hal ini bertujuan untuk pekerja social memberikan pertimbangan bagi hakim mengenai penempatan anak.

5. Lama anak menjalani masa pidana lebih singkat dari pada orang dewasa.

6. Memisahkan pelaku delikuensi anak dengan pelanggaran dewasa selama anak menjalani proses peradilan.

7. Dalam menangani kasus delikuensi harus diputuskan lebih cepat dari kasus orang dewasa dan disposisi atau penempatan hakim harus bervaria.

Pada Konvensi Hak Anak (Convention on the Rights of the Child) yang diratifikasi oleh pemerintah Indonesia melalui Kepres No 36 Tahun 1990. Hal ini juga dituangkan dalam UU No 4 Tahun 1979 tentang Kesejahteraan Anak dan UU No 35 Tahun 2014 tentang Perlindungan Anak yang semuanya mengemukakan poin-poin tentang perlindungan anak, yaitu nondiskriminasi, kepentingan terbaik bagi anak, kelangsungan hidup dan tumbuh kembang, dan menghargai partisipasi serta pendapat anak. Dengan adanya pengesahan konvensi tersebut maka semua pihak memiliki tanggung jawab dan wajib untuk melindungi anak termasuk Aparatur Penegak Hukum.(Pangalila, 2018) Kaitannya dengan Hak Asasi Manusia, Konvensi Hak Anak memiliki arti sebagai berikut(Fatonah, 2009): 
1. Menegaskan berlakunya hak asasi manusia bagi semua tingkatan usia.

2. Meningkatkan standar hak asasi manusia agar lebih sesuai dengan anak-anak, misalnya seperti kondisi kerja, penyelenggaraan peradilan pidana anak serta kondisi perenggutan kemerdekaan.

3. Mengatur masalah-masalah yang khusus berhubungan dengan anak.

Inti sari dari Pasal 1 angka (1) UU No 11 Tahun 2012 Tentang Sistem Peradilan Pidana Anak bahwa Sistem peradilan pidana anak adalah keseluruhan proses atau tata cara untuk menyelesaiakan perkara anak yang berhadapan dengan hukum dimulai dari penyidikanpenyelidikan oleh kepolisian, penuntutan oleh jaksa penuntut umum, diadili oleh hakim di pengadilan dan melaksanakan putusan pengadilan atau tahap pembimbingan. Seluruh proses tersebut berdasarkan asas perlindungan, keadilan, non diskriminasi, kepentingan terbaik bagi anak, penghargaan terhadap harkat dan martabat.(Z.A., 2018)

Diversi sebagai jalan tengah dalam meminimalisir hal tersebut, menurut UU No.11 Tahun 2012 Tentang Sistem Peradilan Pidana Anak, Pasal 7 angka (7) Diversi adalah pengalihan penyelesaian perkara Anak dari proses peradilan pidana ke proses diluar peradilan pidana. Melalui diversi anak dapat dihindarkan dari adanya stigmatisasi oleh masyarakat, mencegah anak menjadi pribadi yang lebih buruk akibat prisonisasi di lapas. Maka dari itu terdapat perlakuan-perlakuan khusus yang diberikan oleh Undang-Undang ini yang bertujuan agar perkembangan fisik dan psikologis anak tidak terganggu. Berikut tujuan diversi menurut undang-undang SPPA (Undang-Undang No 11 Tahun 2012 Tentang Sistem Peradilan Pidana Anak, 2012):

a. Berhasil meraih kesepakatan pemufakatan antara anak korban dan Anak pelaku;

b. memecahkan perkara Anak di luar proses peradilan;

c. untuk menghindarkan Anak dari hukuman perampasan kemerdekaan;

d. mendorong masyarakat agar ikut serta berpartisipasi; dan

e. menanamkan dan menumbuhkan rasa tanggung jawab kepada Anak.

Secara harafiah Diversi adalah suatu wujud perlindungan hukum yang dilakukan oleh Negara kepada anak dalam upaya menghargai dan menaungi segala hak asasi anak dan berbagai bentuk kebebasan yang dimilikinya. Derajat anak sama seperti manusia secara utuh sehingga hak asasi anak merupakan bentuk dari Hak Asasi Manusia (HAM) itu sendiri. HAM sebagai hak mutlak telah melekat pada diri manusia sejak dis hidup. HAM tidak dapat dicabut ataupun dibagi-bagi. Konvensi hak anak sebuah kesepakatan yang mengikat secara hukum dan bersifat politik diantara berbagai Negara yang didalamnya mengatur hal-hal yang berhubungan dengan anak, hal ini menyatakan bahwa hak anak merupakan hak asasi manusia untuk anak.(Fatonah, 2009) Anak mempunyai kebutuhan-kebutuhan khusus yang berkaitan dengan kondisi anak yang masih rentan, ketergantungan dengan 
keluarga dan masih dalam fase perkembangan. Hal tersebut yang melatarbelakangi adanya hak asasi untuk anak.

Diversi dilakukan berdasarkan Restorative Justice Dijelaskan dalam Pasal 1 angka (6) UU No 11 Tahun 2012 Tentang Sistem Peradilan Pidana Anak, bahwa keadilan restorative merupakan penyelesaian perkara tindak pidana dengan cara musyawarah yang melibatkan anak korban, anak pelaku, keluarga korban dan pelaku, dan pihak-pihak yang terkait untuk bersama-sama mencari solusi dan penyelesaian yang adil dengan menitik beratkan pemulihan kembali pada keadaan semula dan bukan merupakan pembalasan. Ketika kesepakatan antara kedua belah pihak tidak terjadi dalam diversi atau kesepakatan diversi tidak dilaksanakan, maka proses peradilan pidana anak akan dilanjutkan. Namun saat peradilan dilanjutkan harus memperhatikan kepentingan anak dalam memberikan hukuman, hakekat seorang anak dan mengutamakan keadilan restorative yang berdasarkan pada pasal 5 ayat (1) UU SPPA.

Anak yang berkonflik dengan hukum harus dihindarkan dari siksaan, hukuman yang kejam dan tidak manusiawi, hukuman mati, hukuman seumur hidup tanpa kemungkinan untuk bebas, dan Negara harus menjamin setiap anak tersebut mendapat jaminan sebagai berikut (Fatonah, 2009) :

1. Anak dianggap tidak bersalah sampai terbukti bersalah menurut hukum atau dalam hukum pidana disebut praduga tak bersalah (presumption of innocent)

2. diberitahu segera atas tuduhannya termasuk kepada orang tua atau walinya

3. mendapat bantuan hukum dan bantuan lainnya ditangani oleh pihak yang berkompeten dan independen

4. tidak dipaksa memberi kesaksian atau mengakui bersalah ; untuk memeriksa saksi yang memberatkan serta mendapatkan partisipasi dan pemeriksaan saksi atas namanya dengan memakai prinsip persamaan.

5. Berhak atas kasasi

6. Mendapat bantuan juru bahasa/ interpreter secara gratis

7. Privasinya sepenuhnya di hormati.

Namun kenyataannya anak yang berkonflik dengan hukum sebelum melalui proses hukum terlebih dahulu mendapatkan pelabelan atau stigma dari lingkungan sosial dengan menyebutnya sebagai anak nakal, anak kriminal dan lain sebagainya.(Setyawati, 2007) Hal ini harus dicegah agar anak tidak menjadipribadi yang lebih buruk. Pemerintah Indonesia sendiri sudah melakukan usaha pencegahan hal tersebut dengan mengacu pada UU No 11 Tahun 2012 Tentang Sistem Peradilan Pidana Anak, yang mengatur mengenai diversi. Secara nyata sebagai jaminan Diversi hadir untuk memberikan perlindungan hukum bagi anak yang berkonflik dengan hukum, sehingga terhindar dari stigmatisasi dan anak dapat kembali ke dalam lingkungan social masyarakat. 
Berdasarkan latar belakang yang diuraikan diatas terdapat permasalahan yang akan di bahas, yaitu : 1) Bagaimana penerapan diversi sebagai implementasi hak asasi manusia anak yang berkonflik dengan hukum ? dan 2) Apa hambatan yang dihadapi oleh pihak terkait dalam melaksaakan diversi ?

Penelitian ini bertujuan untuk mengetahui bagaiaman pelaksanaan diversi sebagai implementasi hak asasi manusia anak yang berkonflik dengan hukum serta mengetahui kendala-kendala yang dihadapi dalam pelaksanaan diversi.

\section{METODOLOGI}

Penelitian ini menggunakan metode penelitian deskriptif kualitatif. Dengan menggunakan studi kepustakaan yang diperoleh dari berbagai sumber data yang ada, baik data primer maupun data sekunder. Studi kepustakaan merupakan teknik pengumpulan data dengan cara menyatukan informasi yang relevan dengan topik atau masalah yang menjadi obyek penelitian. Menurut Koentjaraningrat, metode penelitian kualitatif merupakan suatu jenis penelitia yang menggunakan 3 format antara lain a) deskriptif, b) verifikasi dan c) grounded research, dengan karakteristik cenderung melakukan kajian yang cermat terhadap berbagai gejala social dalam masyarakat, baik secara individu ataupun dalam kelompok sosial.

Menurut Creswell (2008), metode penelitian kualitatif adalah proses penelitian untuk memahami masalah-masalah social atau manusia dengan menganalisis kata-kata untuk menciptakan gambaran kompleks dan menyeluruh serta melaporkan pandangan informasi terpperinci yang diperoleh dari para sumber informasi dalam lingkungan alami.

Informasi diperoleh dari buku-buku, karya ilmiah, tesis, disertasi, ensiklopedia, internet, dan sumber-sumber lain. Dengan menggunakan studi kepustakaan, peneliti bisa memanfaatkan semua informasi dan pemikiran-pemikiran yang relevan dengan penelitiannya. (Unknow, 2016).

Data Primer meliputi :

1. UUD Negara Republik Indonesia Tahun 1945

2. UU No 11 Tahun 2012 Tentang Sistem Peradilan Pidana Anak

3. UU No 35 Tahun 2014 tentang Perubahan atas UU No. 23 Tahun 2002 Tentang Perlindungan Anak.

4. Peraturan Pemerintah No.65 Tahun 2015 Tentang Pedoman Pelaksanaan Diversi dan Penanganan Anak yang Belim Berumur 12 (Dua Belas) Tahun.

5. Peraturan Mahkamah Agung (PERMA) No. 4 Tahun 2014 Tentang Pedoman Pelaksanaan Diversi dalam Sistem Peradilan Pidana Anak.

6. Konvensi Hak Anak (Convention on the Rights of the Child) yang diratifikasi oleh pemerintah Indonesia melalui Keputusan Presiden Nomor 36 Tahun 1990 dengan 
dilengkapi Instrument Internasional antara lain: Beijing Rules tanggal 29 November 1985, The Tokyo Rules tanggal 14 Desember 1990, Riyadh Guidelines tanggal 14 Desember 1990, dan Havana Rules tanggal 14 Desember 1990

Data Sekunder meliputi : Buku-buku referensi yang memiliki keterkaitan dengan judul jurnal, artikel atau jurnal hukum dan hak asasi manusia, dan laporan hasil penelitian yang didapat melalui media cetak maupun media online.

\section{HASIL DAN PEMBAHASAN}

\section{Diversi sebagai Implementasi Hak Asasi Manusia Anak Berkonflik Dengan Hukum}

Sistem Peradilan Pidana di Indonesia setelah berlakunya Undang-Undang Nomor 8 tahun 1981 memiliki 4 subsistem, yaitu :

1. Sub Sistem Kepolisian.

2. Sub Sistem Kejaksaan.

3. Sub Sistem Pengadilan.

4. Sub Sistem Lembaga Pemasyarakatan.

Sebagai subsistem yang berada di luar aturan tersebut yaitu penasehat hukum (advokat dan pengacara) yang merupakan bagian dari aparat penegak hukum yang memiliki peranan penting dalam proses penegakan hukum. Untuk penanganan kasus anak terdapat pihak lain yang juga memiliki peran penting dalam kasus anak, yaitu Pekerja social atau yang disingkat Peksos.

Pada pelaksanaannya seluruh pihak yang terlibat dalam pnanganan kasus anak harus memiliki pemahaman dan kemampuan untuk menangani anak. Karena anak berbeda dari orang dewasa dan harus diperlakukan secara khusus. Menurut Dr. Mansyur, penanganan Anak berkonflik dengan hukum melalui jalur nonformal atau dapat dilakukan dengan cara diversi sebagai prses mediasi yang di fasilitasi oleh penegak hukum pada setiap tahapan peradilan untuk mencapai keadilan restorative yang dapat diselesaikan dengan memberikan kewajiban untuk anak yang berkonflik dengan hukum mengikuti pendidikan atau pelatihan pada lembaga tertentu seperti berupa tindakan lainnya yang dilakukan dengan pemulihan bagi anak pelaku dan korban.(Sinaga, 2017) Menurut Dr. mansyur, untuk hasil yang baik maka harus diimbangi upaya menciptakan system peradilan yang kondusif. (Sinaga, 2017)

Diversi dalam pelaksanaannya sebagai hak anak merupakan salah satu bagian implementasi dari upaya Negara didalam memberikan perlindungan bagi hak anak. Dalam perspektif HAM perlindungan hukum bagi anak yang berkonflik dengan hukum merupakan salah satu dari serangkaian kewajiban yang dimiliki oleh Negara. Hal ini dimaksudkan untuk: menghormati (to respect), melindungi (to protect), dan memenuhi (to fulfill) yang merupakan bentuk kewajiban Negara dalam perlindungan HAM. Dimana secara normatif kewajiban negara tersebut berlandaskan pada standar Hak Asasi Manusia Internasional 
maupun Konstitusi (termasuk ketentuan HAM secara nasional) dan secara operasional ditujukan untuk memajukan pelaksanaan HAM. Dalam pembahasan ini penulis akan menggunakan analisis berupa peraturan dan teori untuk mendalami fokus penelitiaan diatas sehingga penelitian ini berdasar serta dapat dipertanggung jawabkan, adapun penjelasannya sebagai berikut ;

Menurut Anna Pangalila dalam penelitiannya, Dasar hukum penerapan diversi sesuai dengan perkembangan hukum dan perubahan system peradilan anak sesudah berlakunya UU No. 11 Tahun 2012.(Pangalila, 2018) Dasar hukum penerapan diversi yaitu :

1. UU No 11 Tahun 2012 Tentng SPPA, BAB II Pasal 6 s/d Pasal 15

2. Permen No.65 Tahun 2015 Tentang Pedoman Pelaksanaan Diversi dan Penanganan Anak yang Belum Berumur 12 (Dua Belas) Tahun.

\section{PERMA No. 4 Tahun 2014 Tentang Pedoman Pelaksanaan}

Diversi dalam SPPA mengacu pada dasar hukum diatas maka penerapan diversi adalah sebagai berikut :

a. Subjek Tindak Pidana diberlakukan pada anak yang berumur 12 tahun tetapi belum 18 tahun termasuk didalamnya yang sudah pernah kawin yang diduga melakukan perbuatan pidana.

b. Objek Tindak Pidana pada pasal 7 ayat (2) UU No 11 Tahun 2012 menjelaskan bahwa diversi dapat diupayakan pada anak yang melakukan tindak pidana dengan ancaman hukuman dibawah tujuh tahun dan bukan pengulangan tindak pidana (residivis) .

c. Diversi dilakukan harus dengan persetujuan korban, kecuali tindak pidana pelanggaran, tipiring, tindak pidana tanpa adanya korban, kerugian yang di timbulkan anak pelaku tidak lebih dari upah minimum propinsi.

Menurut penelitian Anna Esther Pangalila dalam proses peradilan tidak boleh mengabaikan hak-hak dasar anak sebagai hak asasi manusia anak karena anak berhak atas kesejahteraan, perawatan, pengasuhan dan bimbingan berdasarkan kasih sayang, baik dalam kelvarganya maupun di dalam pengasuhan khusus untuk tumbuh kembang anak.(Pangalila, 2018)

Negara telah membuat peraturan yang menunjang terpenuhinya hak anak terutama dalam hal diversi. Dari sini dapat kita pahami bahwa pelaksanaan diversi bagi anak yang berkonflik dengan hukum sudah diatur sedemikian rupa agar bisa mewujudkan kepentingan terbaik bagi anak. Sebagai suatu sistem yang baru lahir setelah ditetapkan dalam UU No.11 Tahun 2012 diversi sudah menjadi dasar bagi peradilan pidana anak sehingga dalam pelaksanaannya wajib diterapkan. Bisa dikatakan bahwa diversi memiliki peran yang sangat penting dalam memberikan perlindungan terhadap hak-hak asasi anak. Berikut skema tata cara diversi yang dilakukan disetiap tahapan peradilan, mulai dari penyidikan dan 
penyelidikan di kepolisian, penuntutan oleh kejaksaan dan mengadili di pengadilan berdasarkan UU SPPA .

\section{Skema 1}

Tata Cara Diversi di Kepolisian

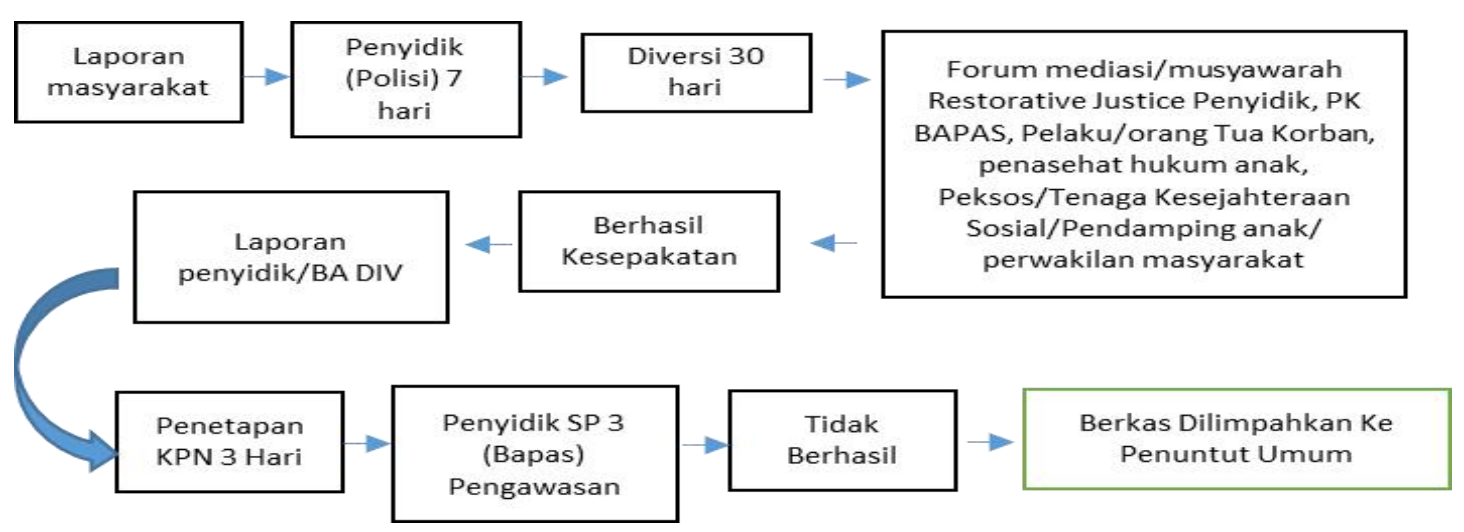

Sumber: UU SPPA

Skema 2

Tata Cara Diversi di Kejaksaan

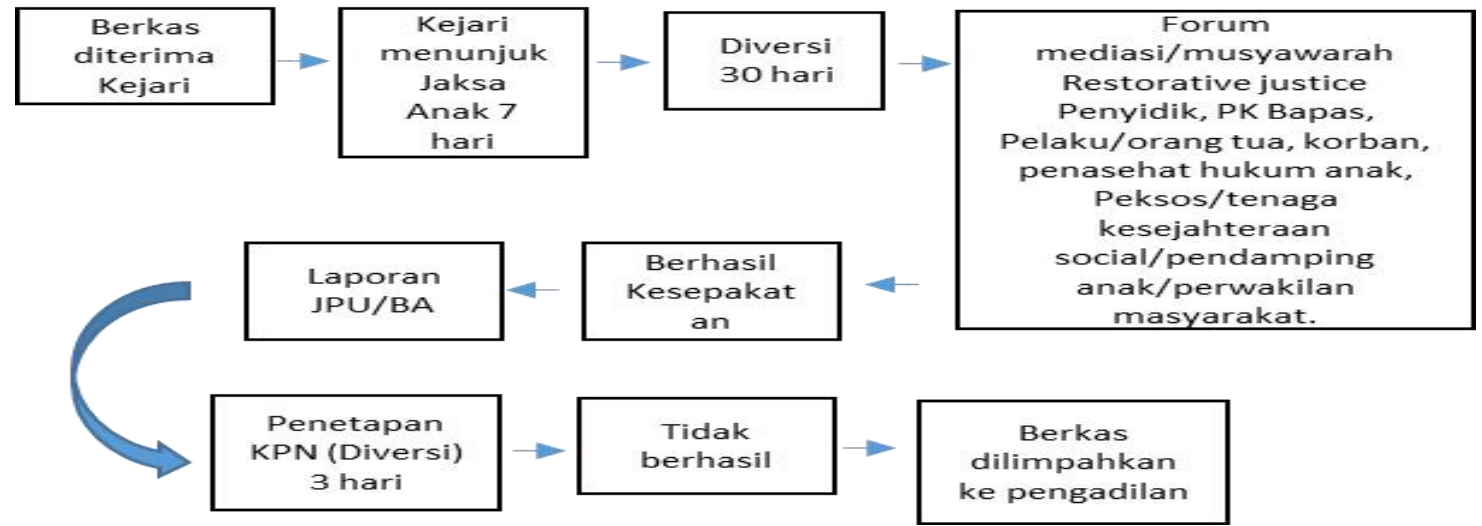

Sumber : UU SPPA

Skema 3

Tata Cara Diversi di Pengadilan
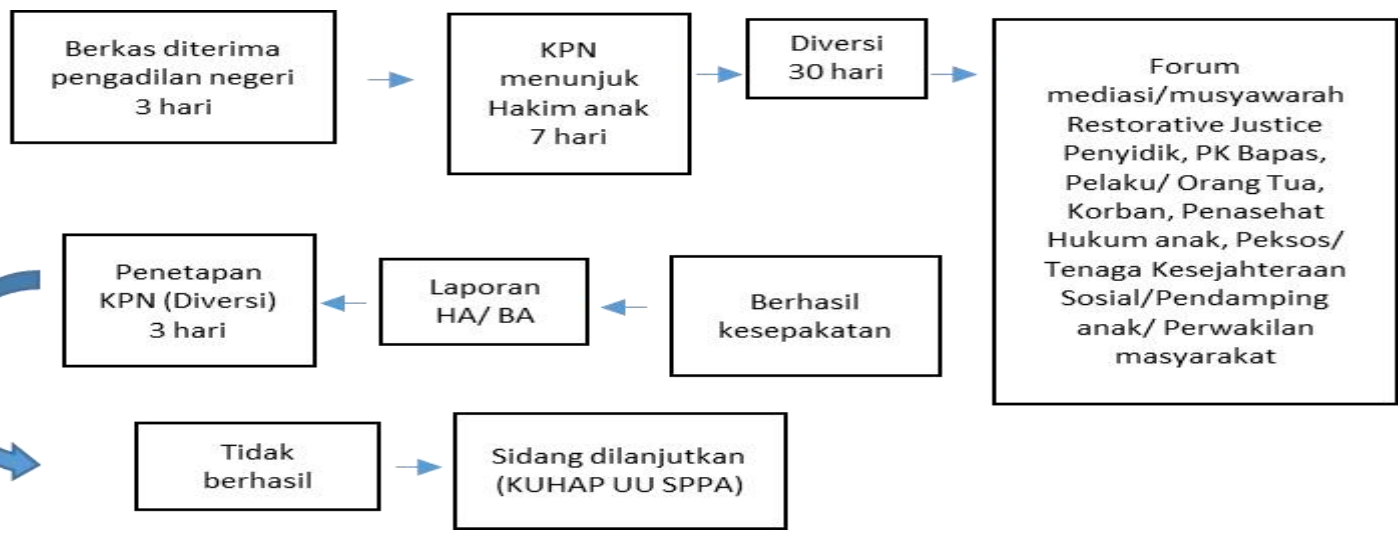

Sumber : UU SPPA 
Dalam skema ini menjelaskan bahwa ketika pelaksanaan diversi tidak bisa di laksanakan maka akan dilanjutkan pada proses selanjutnya namun tetap diusahakan untuk mendapatkan kesepakatan bersama untuk melakukan diversi hingga keputusan final pada pengadilan dan keputusan yang diambil tetap memperhatikan peraturan yang berlaku. Dari skema tersebut dapat di pahami juga bahwa penyelesaian diversi dilakukan berdasarkan keadilan restorative yakni musyawarah mufakat dengan melibatkan berbagai pihak-pihak terkait (anak korban, anak pelaku, keluarga korban dan pelaku, dan pihak-pihak lain yang terkait) yang secara bersama-sama mencari solusi untuk menyelesiakan perkara anak dengan menitikberatkan pemulihan bukan pembalasan ataupun penjeraan. Kepastian pelaksanaan diversi terlihat dari diterapkannya dalam setiap tingkatan pelaksanaan peradilan pidana sesuai dengan sekema diatas. Implementasi diversi selain untuk melindungi anak pelaku juga untuk melindungi anak korban. Dapat dilihat pada pasal 8 ayat (3) UU No 11 Tahun 2012 Tentang Sistem peradilan Pidana Anak yaitu : Proses diversi wajib memperhatikan : a) kepentingan korban; b) kesejahteraan dan tanggung jawab Anak; c) penghindaran stigma negative; d) penghindaran pembalasan; e) keharmonisan masyarakat; dan f) kepatutan, kesusilaan dan ketertiban umum. Mengingat tersangka adalah seorang anak, maka di setiap tahapan pelaksanaan peradilan, anak wajib didampingi oleh Pembimbing kemasyarakatan (PK). Anak dianggap masih membutuhkan bantuan untuk dari orang dewasa untuk memenuhi kebutuhannya, untu menentukan pilihannya dan membantu mendapatkan haknya. Berikut penjelasan mengenai pihak-pihak yang terlibat dalam pelaksanaan musyawarah diversi :

1. Anak Pelaku adalah Anak yang berkonflik dengan hukum, dan di upayakan diversi.

2. Korban adalah Orang yang mengalami kerugian akibat tindak pidana yang di lakukan oleh anak pelaku.

3. Keluarga Anak Pelaku dan Korban

4. Tokoh Masyarakat seperti ketua Rt, Rw, kepala lingkungan, kepala desa tempat tinggal anak pelaku.

5. Guru tenaga pengajar dari tempat anak pelaku bersekolah.

6. Penyidik kepolisian, dijelaskan dalam Pasal 26 ayat (3) UU SPPA, syarat yang ditetapkan sebagai penyidik anak adalah sudah memiliki pengalaman sebagai penyidik, memiliki minat, perhatian dan mampu memahami masalah anak serta sudah mengikuti pelatihan teknis tentang system peradilan pidana anak.

7. Penuntut Umum, dijelaskan dalam pasal 41 UU SPPA mengenai penuntutan terhadap anak dilakukan oleh penuntut umum. Syarat penuntut umum anak yaitu sudah memiliki banyak pengalaman sebagai penuntut umum, memiliki minat, dedikasi dan mampu 
memahami masalah yang di hadapi anak serta sudah pernah mengikuti pelatihan teknis mengenai system peradilan pidana anak.

8. Hakim adalah orang berwenang melakukan pemeriksaan sidang pengadilan terhadap perkara anak dengan syarat sudah memiliki pengalaman sebagai hakim dalam lingkup peradilan umum, memiliki minat, perhatian, dedikasi dan dapat memahami masalah yang di hadapi oleh anak, serta hakim tersebut sudah mengikuti pelatihan mengenai system peradilan pidana anak. Hal ini diatur dalam pasal 43 UU SPPA.

9. Pembimbing Kemasyarakatan adalah petugas dari Balai Pemasyarakatan yang memiliki tugas dan fungsi untuk membuat laporan penelitian kemasyarakatan, pembimbingan, pendampingan dan pengawasan terhadap anak yang berhadapan dengan hukum. Pekrja social professional dan tenaga kesejahteraan social yang sudah memenuhi syarat berupa berijazah paling rendah Strata-1 atau Diploma IV di bidang pekerjaan social atau kesejahteraan social. Memiliki pengalaman kerja minimal 2 tahun di bidang praktik pekerjaan social dan kesejahteraan social, memiliki keterampilan dan keahlian khusus dalam bidang pekerjaan social, memiliki minat dan dedikasi serta perhatian untuk memahami permaslaahan yang dihadapi oleh anak, sehingga peksos dapat membantu membimbing anak demi kelangsungan hidup dan perkembangan fisik anak.

10. Pengacara yang memberikan bantuan hukum selama anak menjalani peradilan.

11. Pihak-pihak lain yang terkait dalam kasus anak.

Pembimbing kemasyarakatan apabila di lihat pada skema 1 bertugas untuk membuat laporan penelitian kemasyarakatan (Litmas). Litmas ini dapat membantu penyidik untuk mengetahui profiling anak, latar belakang anak melakukan tindak kejahatan. Litmas diversi bertujuan untuk membantu penyidik anak, penuntut umum anak dan hakim anak guna kepentingan pemeriksaan dalam proses persidangan, hal ini d atur dalam Pasal 9 angka (1) huruf c UU No 11 Tahun 2012 Tentang Sistem Peradilan Pidana Anak. Adanya standar kualitas yang baik dalam pembuatan laporan penelitian kemasyarakatan oleh pembimbing kemasyarakatan, karena laporan tersebut di gunakan oleh hakim sebagai dasar pertimbangan mengambil keputusan untuk anak. Kesepakatan diversi menurut Pasal 10 ayat (2) UU SPPA adalah dalam bentuk: 1) Pengembalian kerugian apabila ada korban dalam tindak pidana yang di lakukan oleh anak; 2) rehabilitasi medis dan psikososial; 3) penyerahan kembali kepada orang tua / wali; 4) keikutsertaan dalam pendidikan atau pelatihan di lembaga pendidikan atau LPKS paling lama 3 bulan atau 5) pelayanan masyarakat paling lama 3 bulan.

Korelasi antara restoratife justice dan diversi adalah terciptanya suatu kewajiban bersama para aparat penegak hukum didalam melaksanakan suatu proses terhadap anak 
yang berkonflik dengan hukum, dimana bersama-sama mengatasi permasalahan yang ada dan mengutamakan segala sesuatunya menjadi lebih baik bagi kepentingan anak. Pelaksanaan proses ini akan melibatkan berbagai pihak termasuk melibatkan korban, anak pelaku, keluarga korban dan keluarga anak pelaku serta kontribusi masyarakat secara utuh dimana pihak ini akan bersama-sama mencari penyelesian dan solusi untuk memperbaiki keadaan yang terbaik untuk anak dan tidak berdasarkan pada pembalasan.

Begitu besar tanggung jawab Negara berkewajiban menjamin anak mendapatkan hak-hak tersebut. Terutama di Indonesia yang notabene sebagai negara yang berlandaskan hukum dimana akan mengedepankan hukum sebagai pelaksanaan dalam proses bernegara. Berdasarkan pada teori Negara hukum di Indonesia yang tercantum dalam pasal 1 ayat (3) UUD NRI 1945 menyatakan bahwa Negara Indonesia merupakan Negara hukum. Makna dari pasal tersebut menyatakan bahwa kedudukan Indonesia sebagai Negara yang berlandaskan atas hukum dan bukan sekedar kekuasaan saja, hal ini menyatakan bahwa Negara Indonesia dibangun berdasarkan atas kedaulatan hukum sebagai kekuasaan tertinggi. Konsep Negara hukum menurut F.J Sthall terdiri atas empat unsur, yaitu:

1. Mengakui dan melindungi hak-hak asasi manusia;

2. Untuk melindungi hak asasi tersebut, penyelenggara Negara harus berdasarkan pada teori trias politica;

3. Dalam menjalankan tugasnya pemerintah berdasarkan pada Undang-Undang (Wetmatig Bestuur);

4. Apabila dalam menjalankan tugasnya berdasarkan UU, pemerintah masih melanggar hak asasi (campur tangan pemerintah dalam kehidupan pribadi seseorang), ada pengadilan administrasi yang akan menyelesaikannya.

Berdasarkan teori di atas dapat kita kaitkan dengan penelitian ini dimana hukum memiliki peranan yang sangat penting untuk memecahkan peristiwa hukum, dimana dalam menegakkan hukum Negara mengacu pada Undang-Undang peraturan pelaksana yang sudah ditetapkan. Hal ini diartikan bahwa semua orang yang berada di dalam suatu Negara harus memiliki kepatuhan serta tuntuk terhadap hukum yang berlaku (hukum positif). Dalam menerapkan konsep Negara hukum, Negara seharusnya memandang secara netral dan tidak boleh membeda-bedakan suku, ras, agama, gender, dan lain sebagainya. Sehingga semua yang berkedudukan sebagai Warga Negara berhak mendapatkan hukum yang tidak berkepihakan termasuk seorang anak. Ketika kita kaitkan dengan penanganan kasus anak berkonflik dengan hukum, maka dapat diketahui bahwa UU No 11 Tahun 2012 tentang Sistem Peradilan Pidana Anak telah memenuhi keseluruhan poin itu dan mendasari semua ketentuan mengenai penanganan anak yang berkonflik dengan hukum. Sebagai elemen 
dari Negara, seluruh masyarakat termasuk aparat penegak hukum seyogyanya mematuhi dan mengikuti ketentuan dalam Undang-Undang tersebut.

Perbedaan yang begitu besar dalam mengahadapi anak yang berkonflik dengan hukum dibandingkan dengan menangani orang dewasa. Karena, seorang anak dianggap belum mampu untuk mempertanggungjawabkan perbuatan yang dilakukannya baik itu secara sadar. Kemudian seorang anak belum bisa memberikan perbedaan antara mana yang benar dan mana yang salah atau mana yang dapat dilakukan dan mana yang tidak. Maka dari pada itu Negara dalam hal ini Pemerintah Indonesia berkewajiban melaksanakan semua peraturan termasuk peraturan pelaksana terutama mengenai peradilan anak dalam Undang-Undang Sistem Peradilan Anak dimana bertujuan untuk melindungi hak asasi anak.

Sedangkan menurut teori Negara kesejahteraan, Negara melalui pemerintahannya menjamin terselenggaranya kesejahteraan bagi rakyat. Ada lima pilar yang menjadi dasar Negara untuk mensejahterakan rakyatnya, yaitu : Demokrasi, penegakan hukum, perlindungan hak asasi manusia, keadilan sosial dan anti diskriminasi. (Bathara Kresno, 2018). Dalam UU SPPA disebutkan bahwa "anak merupakan bagian yang tidak terpisahkan dari keberlangsungan hidup manusia dan keberlangsungan sebuah bangsa dan Negara". Maka dari itu Negara menjamin hak-hak dari setiap anak atas kelangsungan hidupnya, dihindarkan dari diskriminasi dan mendapat perlindungan dari kekerasan. Stigmatisasi atau labeling yang di berikan kkepada anak berakibat sangat fatal bagi anak, karena anak akan mengalami diskriminasi dari lingkungan sosialnya. Stigma tersebut akan menghambat tumbuh kembang anak baik dari segi fisik maupun mental. Akan lebih parah lagi ketika stigma tersebut makin memperparah gangguan yang dialami oleh anak sehingga anak cenderung berprilaku lebih buruk.

Menurut Prof. Mr. R. Kranenburg menyatakan bahwa Negara harus secara aktif mengupayakan kesejahteraan, bertindak adil yang dapat dirasakan seluruh masyarakat secara merata dan seimbang, bukan mensejahterakan golongan tertentu tapi seluruh rakyat.(Bathara Kresno, 2018) Sehingga sebagai bagian yang tidak dapat terpisahkan dari Negara, seorang anak seharusnya mendapatkan jaminan hak dalam keberlangsungan hidupnya. Kesejahteraan yang baik nantinya akan berdampak baik terutama bagi seorang anak yang akan menjadi masa depan bagi suatu negara. Jika dikaitkan dengan diversi sebagai impelementasi hak asasi manusia anak dapat kita lihat bahwa Negara Indonesia sudah melaksanakan kewajibannya untuk mengupayakan apa yang menjadi dasar dari Negara kesejahteraan, yaitu demokrasi untuk anak, perlindungan hukum untuk anak, perlindungan hak asasi manusia anak, keadilan social anak dan anti diskriminasi untuk anak yang semuanya dituangkan dalam Undang-Undang No 11 tahun 2012 tentang Sistem Peradilan Pidana Anak. Maka dari itu, melalui peraturan ini Negara secara signifikan sudah 
menekan penurunan pelanggaran hak asasi anak dan berusaha untuk melindunginya demi pertumbuhan dan perkembangan mental anak.

Anak yang berhasil ke luar dari proses peradilan pidana melalui diversi di harapkan mampu memiliki tanggung jawab dan bisa belajar dari apa yang telah di alaminya. Anak bisa menjadi pribadi yang lebih baik dan bisa membedakan perbuatan yang baik dan yang buruk. Dalam masa pelaksanaan kesepakatan diversi, anak di berikan pengawasan untuk mengontrol tingkah lakunya.

\section{Hambatan yang dihadapi oleh pihak terkait dalam melaksaakan diversi}

Menurut Indriyatini dalam penelitiannya yang berjudul Hambatan Dalam Pelaksanaan Diversi Pada Anak Yang Berkonflik Dengan Hukum Oleh Penuntut Umum Di Kejaksaan Negeri Wonosari menyatakan bahwa hambatan dalam pelaksanaan diversi dapat digolongkan menjadi dua bagian, yaitu :

1. Hambatan internal yang meliputi : a) dalam melaksanakan musyawarah diversi untuk mencapai kesepakatan antara pihak korban dan pihak pelaku dengan hukum dan b) Sumber Daya Manusia (SDM) terkait penuntut umum khusus anak.

2. Hambatan eksternal: a) terbatasnya sarana dan prasarana yang memadai dalam proses diversi; b) pemahaman yang berbeda-beda dalam penanganan anak yang berkonflik dengan hukum diantara aparat penegak hukum; c) koordinasi antara penuntut umum dengan pembimbing kemasyarakatan; d) pemahaman masyarakat mengenai diversi; e) regulasi mengenai pengawasan terhadap pelaksanaan hasil kesepakatan diversi.

Menurut Yulia Kurniaty, dkk dalam penelitiannya yang berjudul hambatan pelaksanaan diversi dalam penyelesaian tindak pidana anak di tingkat pengadilan menyatakan bahwa 1) adanya perbedaan persepsi tentang makna keadilan oleh para pihak yang terkait dalam diversi; 2) tidak dapat melaksanakan diversi karena pelaku tidak memenuhi persyaratan untuk diupayakan diversi sebagaimana diatur dalam pasal 7 ayat (2) huruf a UU No 11 Tahun 2012 Tentang Sistem Peradilan Pidana Anak yang menyatakan bahwa diversi hanya dapat diterapkan pada anak yang melakukan pidana dengan ancaman hukuman pidananya dibawah 7 tahun. (Yulia Kurniaty, Johny Krisnan, 2016)

Dari dua penelitian diatas dapat kita simpulkan bahwa ada beberapa factor yang menghambat pelaksanaan diversi di Indonesia, yaitu :

1. Faktor Internal

a. Pada saat musyawarah diversi tidak menemukan solusi sehingga tidak ada kesepakatan antara kedua belah pihak yang disebabkan oleh kurangnya pemahaman dari kedua pihak mengenai diversi dan betapa pentingnya masa depan anak. 
b. Minimnya sumber daya manusia yang dimiliki oleh aparat penegak hukum yang terlibat dalam proses diversi seperti penyidik khusus anak, jaksa anak, hakim anak, pembimbing kemasyarakatan dan pekerja social. Selain minimnya jumlah petugas, pemahaman dari masing-masing instansi terkait mengenai diversi dirasa masih berbeda-beda. Hal ini karena adanya kecenderungan menilai bahwa instansi tempat mereka bekerja adalah yang paling penting dan memberikan kontribusi paling besar dalam pelaksanaan diversi tanpa mau melihat ataupun mendengarkan pendapat dari orang lain atau biasa disebut dengan egosentrisme.

2. Faktor Eksternal

a. Keterbatasan sarana dan prasarana seperti halnya terbatasnya ruangan untuk melaksanakan musyawarah diversi sehingga biasanya musyawarah diversi dilakukan di luar tempat instansi terkait. Dalam penelitian yang dilakukan oleh Maya Indriyatini di Kejaksaan Negeri Wonosari menyatakan bahwa ruangan tempat musyawarah diversi di kejaksaan negeri wonosari tidak memadai dan terkadang pihak-pihak yang mengikuti diversi tidak mendapatkan tempat duduk dan harus berdiri.

b. Koordinasi antara aparat penegak hukum menjadi salah satu factor penghambat. Seperti halnya pihak balai pemasyarakatan yang terlambat memberikan laporan penelitian kemasyarakatan (Litmas).

c. Perbedaan persepsi antara aparat penegak hukum mengani pelaksanaan SPPA.

d. Orang Tua yang tidak kooperatif untuk mengikuti pelaksanaan musyawarah diversi. Kurangnya pemahaman masyarakat mengenai UU No 11 tahun 2012 Tentang SPPA khususnya dalam hal diversi. Masyarakat masih menganggap bahwa setiap perbuatan pidana yang dilakukan baik itu oleh anak maupun orang dewasa adalah sama cara penyelesaiannya.

\section{KESIMPULAN}

Berdasarkan pembahasan diatas dapat di simpulkan bahwa penerapan diversi merupakan salah satu upaya Negara untuk melindungi hak asasi anak. Peraturan KKonvensi Hak Anak yang sudah diratifikasi oleh Negara Indonesia menjadi dasar dari kewajiban pemerintah untuk melindungi anak. Melindungi anak dari stigmatisasi dari masyarakat, melindungi masa depan anak dan menghindarkan anak dari perampasan kemerdekaan. Diversi memberikan pembelajaran kepada anak untuk memiliki rasa tanggung jawab. Diversi dilakukan dengan cara musyawarah/ Restorative Justice. Semua pihak harus berkonsentrasi dan serius mempersiapkan Sumber Daya Manusia, sarana dan prasarana untuk mendukung sistem peradilan pidana anak. Penyelesaian perkara anak bukan lagi menggunakan pembalasan tetapi dengan memulihkan keadaan menjadi lebih jKurangnya pemahaman mengenai UU No 11 Tahun 2012 Tentang Sistem Peradilan Pidana Anak menimbulkan adanya perbedaan 
pemahaman dari masing-masing aparat penegak hukum yang terlibat didalamnya. Selain itu kurangnya sosialisasi mengenai UU SPPA khususnya diversi kepada masyarakat awam, sehingga penanganan anak yang berkonflik dengan hukum masih kurang dari maksimal. Peran serta masyarakat untuk ikut berpartisipasi dalam penerapan diversi ini kurang maksimal.

\section{DAFTAR PUSTAKA}

Bathara Kresno. (2018). Konsep "Welfare State Theory" Maksimalkan Peran Pemerintah. Kumparan. https://kumparan.com/bathara-kresno/konsep-welfare-state-theorymaksimalkan-peran-pemerintah\%0D

Fatonah, A. N. (2009). Mengenal Konvensi Hak Anak (I). Buana Cipta Pustaka.

Krisna, L. A. (2018). Hukum Perlindungan Anak: Panduan Memahami Anak yang Berkonflik dengan Hukum (R. Fitriani (Ed.)). Deepublish.

Pangalila, A. E. (2018). SISTEM DIVERSI TERHADAP ANAK SEBAGAI PELAKU TINDAK PIDANA DALAM SISTEM PERADILAN DIKAITKAN DENGAN PERLINDUNGAN HAK ASASI MANUSIA. LEX ET SOCIETATIS, 6(4), 94-100.

Setyawati, M. (2007). Perlindungan Anak dalam Rancangan KUHP (E. Cahyadi (Ed.); Cetakan I). ELSAM dan Aliansi Nasional Reformasi KUHP.

Sinaga, D. (2017). Penegakan Hukum Dengan Pendekatan Diversi (Perspektif Teori Keadilan Bermartabat). Nusa Media Yogyakarta.

Undang-Undang No 11 Tahun 2012 Tentang Sistem Peradilan Pidana Anak. (2012). 1-52. Unknow. (2016). Pengertian Studi Kepustakaan. Transiskom.Com. https://www.transiskom.com/2016/03/pengertian-studi-kepustakaan.html Yulia Kurniaty, Johny Krisnan, H. H. (2016). Hambatan pelaksanaan diversi dalam penyelesaian tindak pidana anak di tingkat pengadilan. 39-49.

Z.A., M. S. (2018). SekilasTentang Peradilan Pidana Anak. Mahkamah Agung RI Pengadilan Negeri Palopo. http://www.pn-palopo.go.id/index.php/berita/artikel/363-sekilastentang-sistem-peradilan-pidana-anak 